\title{
POZYTYWNE SKUTKI PANDEMII COVID-19 W OBSZARZE EKOLOGICZNYCH RUCHÓW SPOŁECZNYCH
}

\section{Streszczenie}

Niniejszy artykuł podejmuje temat sytuacji ruchów społecznych, fundacji i grup, które za cel postawiły sobie dbanie o środowisko w mieście, a także zapewnienie swoim członkom ekologicznej żywności, od lokalnych sprzedawców, w dobie pandemii.

Opisano w nim rezultaty badań przeprowadzanych na przełomie sierpnia i września 2020 na terenie Krakowa. Respondentami byli członkowie takich grup jak Krakowski Alarm Smogowy, Fundacja Otwarty Plan, Wawelska Kooperatywa Spożywcza oraz Akcja Ratunkowa dla Krakowa. Poruszony w nim zostaje wpływ izolacji na funkcjonowanie wyżej wymienionych ruchów społecznych, fundacji i grup. Ponadto poruszona w nim została tematyka więzi typu communitas oraz trwałości grup opartych na tym typie więzi społecznych.

Znaczną część artykułu zajmują także prognozy i przypuszczenia co do tego, jak zmienić się może życie w miastach i jaki wpływ na samą miejskość ma kryzys branży usług.

Słowa kluczowe: ekologia, pandemia, ruchy społeczne.

\section{Wprowadzenie}

O potencjalnych skutkach choroby wywołanej przez wirusa Covid-19, zwanej potocznie pandemią koronawirusa, która rozpoczęła się 17 listopada 2019 w mieście Wuhan, po czym rozprzestrzeniła się na cały świat, jak dotąd napisano wiele artykułów. Skupiano się przede wszystkim na wpływie strachu, przewlekłego stresu 
i izolacji na zdrowie człowieka. Dla nikogo nie będzie zaskoczeniem, że jednym ze skutków pandemii, a ściślej czasowej izolacji jest zwiększona zapadalność na choroby psychiczne, w tym depresję czy schizofrenię. Opisywano także potencjalne skutki i przewidywania losów firm globalnych i prognozowano znaczący wzrost bezrobocia, ponieważ ogłoszenie stanu pandemii było najwyższym stopniem alertu, jaki jest wydawany przez WHO, a rządy wielu krajów podjęły restrykcyjne działania mające na celu przeciwdziałanie rozprzestrzenianiu się zachorowań. Ograniczono podróże, wprowadzono przymusowe kwarantanny i godziny policyjne, odroczono lub odwołano szereg wydarzeń sportowych, religijnych i kulturalnych. W Chinach i w Korei Południowej wprowadzono restrykcje, takie jak zakaz opuszczania miejsca zamieszkania. Część państw zamknęła granice lub wprowadziła ograniczenia ruchu granicznego, w tym przylotów pasażerów oraz obostrzenia w stosunku do osób przekraczających granice. Wprowadzono także kontrole na lotniskach i na dworcach kolejowych. Spowodowało to zmianę społeczną, niepokoje i zakłócenia gospodarki w skali globalnej, w tym największą światową recesję od czasów Wielkiego Kryzysu. Doprowadziło to również do opóźnienia lub odwołania wydarzeń zarówno sportowych, jak i religijnych, czy imprez masowych takich jak koncerty. Skutkiem obostrzeń były także czasowe braki w zaopatrzeniu w dobra konsumpcyjne. Pandemia bez wątpienia ma wiele negatywnych skutków, a powrót do stanu gospodarki sprzed jej wybuchu najprawdopodobniej zajmie nam, jako społeczeństwu całe lata. Jednak, paradoksalnie, to właśnie ona może mieć pozytywny wpływ na społeczeństwo i przyczynić się do zwiększenia świadomości ekologicznej, w szczególności w zakresie żywienia.

\section{Ustalenia metodologiczne}

Niniejszy artykuł jest próbą odpowiedzi na pytanie, jak zmieniła się sytuacja krakowskich ruchów społecznych, fundacji i grup, które za cel postawiły sobie poprawę stanu powietrza, zapewnienie ekologicznej żywności oraz zapobieganie złym decyzjom, które mogą mieć negatywny wpływ na środowisko. Jest to opis badań, jakie prowadziłam na przełomie maja i czerwca 2020 roku, a respondenci, którzy zgodzili się wziąć udział w badaniu byli członkami Krakowskiego Alarmu Smogowego, Akcji Ratunkowej dla Krakowa, Fundacji Otwarty Plan oraz Wawelskiej Kooperatwy Spożywczej. Powstał na podstawie niepublikowanej pracy magisterskiej pt. „Ekologiczne ruchy społeczne w dobie pandemii” obronionej 10.09.2020 r. w Krakowie.

Metoda badawcza przyjęta na potrzeby zgromadzenia stosownych informacji to tak zwany wywiad pogłębiony. Należy on do zakresu badań jakościowych, stoso- 
wany jest także w dziedzinie zwanej antropologią kultury lub etnografią (Konecki, 2000). Badania te mogą być wdrożone w sytuacji, gdy badacza interesuje pogłębiona wiedza na dany temat i dotarcie do sedna problemu, przy założeniu, iż nie będzie konieczna reprezentatywność wyników, a raczej poznanie istoty zjawiska. Badania te mają na celu przyjrzenie się „światu zewnętrznemu”, a także opis, interpretację i wyjaśnianie zjawisk społecznych z perspektywy wewnętrznej na wiele rozmaitych sposobów. Jak pisze Uwe Flick w swoim dziele pod tytułem Projektowanie badania jakościowego (2010), działania badacza, który prowadzi badania jakościowe zawierają na przykład analizy doświadczenia jednostek i grup, związane $\mathrm{z}$ indywidualnymi biografiami lub z prywatną albo zawodową praktyką w życiu. Przy pomocy tych metod można dotrzeć do wyżej wymienionych faktów, badając wiedzę potoczną i opowieści z tak zwanej „pierwszej ręki”. Można również obserwować i nagrywać akty interakcji i komunikacji na nośniki do rejestracji dźwięku, a następnie dokonać analizy zebranego materiału.

Jedną z technik w badaniach jakościowych jest przeprowadzenie tak zwanego wywiadu pogłębionego, zwanego również wywiadem swobodnym lub wywiadem etnograficznym. Metoda ta zakłada przygotowanie przez badacza listy poszukiwanych informacji przed przystąpieniem do wywiadu. Panuje tu pewna swoboda $\mathrm{w}$ aranżowaniu sekwencji pytań, a także w sposobie formułowania pytań w zależności od sytuacji wywiadu. Język wywiadu pogłębionego jest uzależniony od kontekstu badań i potrzeb respondentów. Nie jest także ujednolicony dla wszystkich. Przypomina on swobodną rozmowę respondenta z osobą prowadzącą wywiad na dany temat, przy czym rola osoby prowadzącej ogranicza się do właściwej moderacji polegającej na wtrącaniu od czasu do czasu pytania lub prośby o bliższe sprecyzowanie wywodu.

Jan Lutyński wyróżnia pięć typów wywiadu pogłębionego. Jest to typologia wywiadów wg stopnia ich standaryzacji (Konecki, 2000). Pierwszym jest wywiad swobodny mało ukierunkowany. Drugim swobodny ukierunkowany, trzeci to swobodny ze standaryzowaną listą poszukiwanych informacji, czwarty to typ kwestionariuszowy o mniejszym stopniu standaryzacji, zaś piąty to typ kwestionariuszowy o większym stopniu standaryzacji. W badaniach terenowych można stosować wszystkie rodzaje wywiadów, jednak w badaniach terenowych o jakościowym charakterze stosowane są trzy pierwsze rodzaje wywiadów, o względnie niskim stopniu standaryzacji.

Jako metodę badawczą na potrzeby niniejszej pracy zdecydowałam się obrać wywiad pogłębiony, indywidualny. W tej metodzie konieczne jest, aby badający spełnił kilka istotnych warunków (Konecki, 2000). Jest to między innymi odnalezienie właściwego respondenta, który będzie reprezentatywny dla danej grupy. Osoba taka staje się jednym z najważniejszych „informatorów” dla badacza. Ponadto osoba taka musi zgodzić się na rolę tłumacza kulturowych obyczajów, sposobów 
pracy, żargonu, języka i społecznych relacji, jakie panują w danej grupie lub organizacji. Znalezienie tej osoby oraz uzyskanie jej zgody na udział w badaniu niejednokrotnie jest trudne. Drugą istotną kwestią jest konieczność osiągnięcia płaszczyzny porozumienia z respondentem oraz zrozumienie jego perspektywy widzenia świata. Ponadto, relacje pomiędzy badaczem a badaną osobą powinny mieć charakter symetryczny, a osoba odpowiadająca na pytania powinna czuć się partnerem rozmowy. Wywiad musi posiadać wiele cech swobodnej rozmowy, a badacz powinien postarać się przyjąć podobną perspektywę, jaką ma odpowiadający na pytania. Powinien także postarać się spojrzeć na świat z jego perspektywy. W przeciwnym razie ucierpi na tym wiarygodność badań, gdyż otrzymamy jedynie utarte komunały zamiast rzetelnych wyników. $Z$ drugiej strony, badający może zaangażować się zbytnio w życie badanej grupy i stać się na przykład jej reprezentantem na zewnątrz, co prowadzi do utraty dystansu i obiektywności. Wielką rolę odgrywa tu także metoda obserwacji uczestniczącej (Nieporowski, 2015). Jest to najstarsza metoda używana w pracy badacza, a jej elementy występują również w innych metodach, między innymi w wywiadzie. Badacz wchodzi niejako w określone środowisko społeczne, lub w grupę badanych, co pozwala mu poznać jego strukturę. W odróżnieniu od obserwacji nieuczestniczącej, dokonywanej „z zewnątrz”, gdzie badacz występuje z perspektywy biernego obserwatora, pozwala na dokonanie wnikliwej interpretacji. Technika ta polega na obserwowaniu oraz wyciąganiu wniosków, z niewielką ingerencją w interakcje między członkami badanej grupy. Jest to celowe poszukiwanie faktów oraz poznawaniem za pomocą zmysłów. Obserwacja naukowa stanowi proces uważnego i celowego spostrzegania. Cała wartość poznawcza tej metody polega na opisie zjawisk, który jest polem do dalszych, poszerzonych badań. Obserwacja uczestnicząca pozwala zdobyć tak zwaną milczącą wiedzę (Nieporowski, 2015).Ten rodzaj wiedzy wyraża się w działaniu. Jest w odróżnieniu od wiedzy teoretycznej, wiedzą dotyczącą tego, jak coś zrobić (know-how), typową na przykład dla fachowca, który nie zastanawia się, jak postępować w swojej pracy.

W badaniach terenowych nie wolno jednak zapominać o kwestiach etycznych. Powinny być one dla każdego badającego tak ważne jak sprawy metodologii czy teorii, ponieważ problemy etyczne mogą pojawić się na każdym etapie badań jakościowych. Każdy naukowiec powinien kierować się regułami, aby jego badania były zgodne z zasadami etyki. Jest to między innymi świadoma zgoda, jakiej udziela badający, na wzięciu udziału w badaniu. Jeśli zaś nie ma pełnej wiedzy, co do charakteru uczestnictwa, nie będzie to zgodne z kodeksem. Drugą kwestią jest zakaz wprowadzania w błąd respondentów przez badacza, na przykład co do swojej prawdziwej tożsamości. Konieczne jest również poszanowania prywatności badanych, zagwarantowania anonimowości i poufności. Nie wolno również dopuścić do sytuacji, w której jakieś dane zostaną świadomie pominięte przez naukowca w celu ma- 
nipulowania wynikami. Ponadto badacze powinni starać się przewidywać ewentualne szkodliwe konsekwencje badań i zabezpieczyć wyniki. Każdy badacz powinien mieć również świadomość, iż zawsze będzie przybyszem z „zewnątrz.” Każde jego działania będą więc ingerencją $\mathrm{w}$ środowisko badanych, zatem powinien starać się minimalizować swój wpływ.

Wszyscy respondenci wyrazili świadomą zgodę na przeprowadzenie niniejszych badań. Zostały im także udzielone wyczerpujące informacje o tym, jaki charakter będzie miał wywiad oraz jak zostaną wykorzystane wyniki badań. Byli oni również poinformowani o tym, iż ich wypowiedzi będą rejestrowane na urządzeniu do rejestracji dźwięku. Ponadto wszyscy z badanych mieli zapewnioną anonimowość podczas wywiadu. Chciałabym nadmienić w tym miejscu, iż badania te przeprowadzane na Uniwersytecie Jagiellońskim, rozpoczęły się przed ustanowieniem Komisji ds. etyki badań naukowych w Instytucie Europeistyki Uniwersytetu Jagiellońskiego, zatem nie zachodziła konieczność stosowania się do zasad regulaminu wyżej wymienionej Komisji.

\section{Zmiana społeczna spowodowana pandemią}

Wraz z ogłoszeniem stanu pandemii mogliśmy obserwować, jak zmiana społeczna dokonuje się wprost na naszych oczach. Pojęcie zmiany społecznej definiowane jest przez Piotra Sztompkę jako: „różnica między stanem systemu społecznego w jednym momencie czasu” (Bauman, 1999). Stan poprzedni i stan obecny mogą się różnić pod wieloma względami: może nastąpić zmiana składu systemu, gdy pojawiają się nowi członkowie lub dawni odejdą, pewne pozycje ulegną dezaktualizacji, zmienią się lub też powstaną nowe. Może to być także zmiana struktury systemu, będąca modyfikacją powiązań między elementami takimi jak interakcja, interesy, normy i idee. Ten typ nazywany jest także rewolucją. Zmiana społeczna postrzegana jest jako pojedynczy epizod oraz przejście z jednego stanu do drugiego. Oczywistym jest, że zmiany łączą się ze sobą, zazębiają się i jedne pociągają ze sobą drugie. To ciagły proces, a śledzenie go pomaga opisać ciąg sekwencji oraz fazy lub etapy. Zmiana społeczna jest także formą budowy społeczeństwa, ponieważ prowadzi do uznania szeregu strukturalnych i kulturowych ograniczeń sprawców zmiany, czyli nieuchronności występowania zjawisk i procesów życiowych i spontanicznych, wymaga także uwzględnienia szerszej perspektywy czasowej w ujmowaniu zmiany społecznej, w tym rozważenia wcześniejszych przekształceń i ich niekoniecznie korzystnych wpływów na zbiorowości (Niedźwiedzki, 2003).

Pandemia, a raczej wywołany nią kryzys bez wątpienia będzie wielką zmianą społeczną. Chociaż zmian, jak mówi Zygmunt Bauman, „w obliczu wzmożonego 
ich tempa nie można już traktować zmian, jako zdarzeń nadzwyczajnych" (Bauman, 1999). Społeczeństwo przywykło do nich do tego stopnia, że nikt już nie traktuje ich jako odchylenie od normy, a wręcz przeciwnie, jako jedyną stała, to jednak społeczeństwo przywykło do pewnych schematów, pewnych rozwiązań i swobody, jaką dawała globalizacja. Dotychczas zarówno gospodarka jak i kultura popularna opierała się o globalność. Arjun Appadurai w swojej książce zauważył, iż globalizacja traktowana jest, jako proces homogenizacji społeczeństwa, wprowadzone są takie pojęcia takie mcdonaldyzacja (Ritzer, 1997) będąca upowszechnieniem się zasad działania restauracji szybkiej obsługi nie tylko w gastronomii, ale także we wszystkich dziedzinach życia społecznego w Stanach Zjednoczonych Ameryki oraz na całym świecie, czy amerykanizacja, która jest ogólnym określeniem procesów wszelkiego rodzaju zmian kulturowych, zachodzących na skutek wpływu kultury Stanów Zjednoczonych na resztę świata (Amerykanizacja, 2020). Badacz dostrzegł dialektyczny ruch zachodzący w ramach procesu globalizacji, czyli ciągłe wytwarzanie i nieustający rozkład lokalności jednocześnie. Proces ten spowodowany był działalnością mediów oraz migracjami. „W tym kontekście pojawia się terminologia taka jak "przepływy" czy "kaskady" zapożyczone z fraktalnej geometrii i teorii chaosu, a przede wszystkim słynne już "krajobrazy" obrazujące poszczególne wymiary globalizacji” (Appadurai, 2005).

Nośnikiem globalizacji była kultura popularna, która jest czymś, co przekracza granice społeczne, religijne, państwowe i kontynentalne, zaciera różnice narodowe, etniczne i językowe. Jako że zjawisko to szczególnie dotyczy kultury oferowanej przez socialmedia, prawdziwym fenomenem pod tym względem jest kultura młodzieżowa" (Appadurai, 2005). Globalizacja, amerykanizacja i mcdonaldyzacja przejawiała się między innymi na gruncie usług, międzynarodowe sieci sklepów odzieżowych, na przykład Zara czy H\&M, górowały nad lokalnymi, podobnie kawiarnie dostosowane do potrzeb masowego turysty czy multikina wygrywały z małymi, studyjnymi, a wielkie sieci restauracji przynosiły największe zyski. Globalizacja niemal zabiła miejskość, doprowadzała do stopniowego zaniku różnorodności, zarówno wśród społeczeństw, jak i środowisk naturalnych. Jednostki miały spełniać ogólnie przyjęte ramy, a ich rola w społeczeństwie sprowadzała się stopniowo do roli konsumenta dóbr i usług. Człowiek zatracał charakter podmiotu na rzecz jego uprzedmiotowienia i uzależniał się od kupowania produktów konkretnych marek.

Zmiana społeczna, choć może się wydawać, iż zaszła z dnia na dzień, w rzeczywistości był to powolny proces. Jak pisze Paweł Kubicki w swoim artykule Odporność miast musi być oparta na wspólnocie (Kubicki, 2020) w okresie miejskiego odrodzenia przypadającego na przełom XX i XXI wieku miały miejsce nie tylko takie procesy, jak rozwój i rozrost tkanki miejskiej. Triumf miejskości był nie tylko siłą napędową dla gospodarki opartej na sektorach kreatywnych i usługach, ale także 
spowodował gentryfikację, turystyfikację oraz zwiększenie nierówności i wykluczenia społecznego niektórych grup. Już w 2008 roku można było obserwować pierwsze widoczne symptomy nadchodzącej zmiany. W tym roku miał miejsce kryzys, a sposoby jego rozwiązania jedynie przyspieszyły nadchodzącą katastrofę, ponieważ dały pole do rozwoju populizmów i ekstremizmów w miastach europejskich.

Można jedynie spekulować na temat tego, jakie będą skutki pandemii dla przyszłości miast. Wraz z jej wybuchem społeczeństwo odczuło lęk i strach, odnotowany został wzrost zachorowań na depresję i choroby psychiczne, a doświadczenie izolacji przyniosło ryzyko dalszej atomizacji społecznej, gdyż uniemożliwiło budowanie relacji i tworzenie społeczności. Pandemia może zarówno posłużyć do dalszego „dociskania” systemu, kapitalizowania kolejnych obszarów i wprowadzania rozwiązań o charakterze autorytarnym. W skrajnych przypadkach może dojść do tego, że dyskryminowane zostaną najsłabsze grupy społeczne, prawa obywatelskie zostaną ograniczone, a elektroniczny nadzór może stać się normą w wielu krajach.

\section{Prognozy i przewidywane skutki pandemii}

Jednak paradoksalnie, wybuch pandemii Covid-19 stworzył szansę na to, aby zmienić kierunki dotychczasowej polityki opartej na zasadzie „zwycięzca bierze wszystko", oraz na to, by zacząć myśleć o mieście jako o wspólnocie. Rozwój pandemii pokazał słabość takiego modelu, gdyż „biznes nastawiony na szybkie zyski, anonimowego klienta i oparty na pracy prekarnej okazał się mało odporny na kryzys" (Kubicki, 2020). Inaczej rzecz ma się w przypadku usług lokalnych, które choć przynoszą mniejsze zyski, obecnie mają większą szansę na przetrwanie kryzysu, gdyż opierają się na solidarności i relacjach społecznych. Pandemia pozwala też wyraźniej dostrzec alternatywy polityczne, ekonomiczne i ekologiczne. Na naszych oczach zawiązują się sojusze, powstają nowe modele aktywistyczne, stawiane są postulaty i żądania, wyłaniają się socjalne i demokratyczne rozwiązania, które mogą nam posłużyć do tworzenia innej polityki. To, czy progresywne zmiany zostaną wprowadzone, w dużym stopniu zależy od właściwego rozpoznania problemów, wypełnienia programów treścią i konsekwencji w ich wdrażaniu.

Jednym z przewidywanych skutków pandemii jest kryzys branży usług, który według prognoz dotrze do Polski jesienią 2020 roku. Wolność oraz szeroki wachlarz usług od zawsze były magnesem, który przyciągał do miast. Jeśli tego zabraknie, następstwem będzie fala suburbanizacji, obniżenie wydolności budżetów samorządów, a co za tym idzie pogorszenie jakości usług publicznych. W tak ciężkich czasach pole do rozwoju zyskują takie organizacje, jak spółdzielnie czy kooperatywy. Typ więzi łączących ludzi w podobnych grupach nazywany jest communitas (Turner, 2010). 
Termin ten został wprowadzony przez Victora Turnera i opisuje szczególny rodzaj relacji społecznych opartych na wspólnocie, wspólnym udziale, więziach i łączności. Według badacza w communitas kształtuje się specyficzna struktura, w której związki pomiędzy jednostkami przekształcają się w unormowane relacje pomiędzy osobami społecznymi. Wyróżniamy kilka faz tych relacji. Pierwszy z nich to tak zwany egzystencjalny albo spontaniczny. Jest to nietrwały stan, charakteryzujący się dużym ładunkiem najczęściej przyjemnych emocji. Powstaje pomiędzy okresami sprawowania urzędu, posiadania określonego statusu albo pozycji społecznej. Typ drugi to normatywna communitas, która powstaje wtedy, kiedy communitas egzystencjalna przekształca się w trwały system społeczny. Kolejną fazą jest ideologiczna communitas. Określenie to jest najczęściej stosowane do opisu utopijnych modeli społecznych, jako określenie stanu braterskiej harmonii (Turner, 2010).

Communitas angażuje całego człowieka w relacje z drugim, co może wydawać się trudne, ponieważ należy podejmować decyzje korzystne dla grupy, a upodobania są tłumione i podporządkowane życzeniom zbiorowości. Zjawisko communitas manifestuje się na przykład poprzez religijne ruchy millenarystyczne, ale nie tylko, możemy je też zaobserwować tam, gdzie społeczeństwa plemienne znalazły się pod panowaniem społeczeństw industrialnych. Manifestuje się także poprzez cechy liminalne takie jak: homogeniczność, równość, brak własności, zredukowanie wszystkich to tego samego poziomu, jak noszenie jednolitego stroju w przypadku obu płci albo minimalizacja różnic płciowych, czy zniesienie rang.

Sytuacja pandemii stwarza także szansę na odrodzenie lokalności. Lokalność według definicji Arjuna Appaduraia (2020) jest walką tocząca się w wielu wymiarach. Pierwszy z nich to stały wzrost starań nowoczesnego państwa narodowego, aby zdefiniować pod kątem charakterystycznych dla nich form lojalności i przynależności. Drugi to pogłębiające się rozwarstwienie między terytorium, podmiotowością i zbiorowym ruchem społecznym. Trzecie zaś to stała erozja relacji między sąsiedztwami przestrzennymi i wirtualnymi, która jest rezultatem siły oddziaływania i formy elektronicznego przekazu. Kryzys może stworzyć szansę nie tylko na odrodzenie lokalnych sklepów, oferujących produkty regionalne, ale także na odrodzenie lokalności samej w sobie. Jeśli globalne firmy ograniczą swoje wpływy na rynku światowym, utworzy się swoistego rodzaju szczelina w systemie, czyli pusta przestrzeń, którą mogą wypełnić firmy lokalne, zapewniając produkty niejednokrotnie lepszej jakości i w niższej cenie. Kryzys jest także czasem, kiedy ludzie wykazują zdolność do zrzeszania się w obrębie niewielkich społeczności i działania we wspólnej sprawie. Na tej podstawie można przypuszczać, iż kryzys, który według szacunków ma nadejść jesienią 2020 roku, stworzy szansę na odrodzenie lokalności i umocnienie dotąd luźnych więzi. 


\section{Sytuacja badanych grup w dobie pandemii}

Ogólna sytuacja w trakcie pandemii zmieniła się w sposób znaczący. Wiele globalnych firm upadło, wielu ludzi straciło pracę z racji niewydolności systemu opartego na pracy prekarnej. W gospodarce globalnej widać już nadchodzący kryzys, wzrastają na przykład ceny żywności. Jak zmieniła się sytuacja w Krakowskim Alarmie Smogowym, Fundacji Otwarty Plan, Akcji Ratunkowej dla Krakowa oraz w Wawelskiej Kooperatywie Spożywczej? Na potrzeby badań został przygotowany krótki kwestionariusz zawierający trzy pytania, z których ostatnie miało dwa podpunkty. Pierwsze z pytań dotyczyło tego, czy wybuch pandemii Covid -19 wpłynął na działalność ruchów społecznych, grup i fundacji oraz na ich członków i sympatyków. Moim celem było pozyskanie informacji na temat tego, jak badane grupy funkcjonowały podczas epidemii, czy podtrzymały działalność, czy też zostały pokonane przez obecną sytuację. Drugie z pytań brzmiało: „Czy obserwuje Pan/Pani zmianę w postępowaniu członków i sympatyków wywołaną czasową izolacją?”. Chciałam dowiedzieć się, czy ludzie poczynili refleksje na temat swojego postępowania. Trzecie zaś dotyczyło prognoz na dalszą działalność ruchu, fundacji, grupy czy kooperatywy w dobie kryzysu wywołanego pandemią.

Na pierwsze z pytań odpowiedzi były podobne. Respondent z Akcji Ratunkowej dla Krakowa odpowiedział, iż wybuch pandemii znacząco wpłynął na grupę. Spotkania wprowadzające w działalność, organizowane co dwa tygodnie, przeznaczone dla nowych członków zostały czasowo zawieszone. Spotkania dla stałych członków przeniesiono do przestrzeni internetowej, gdzie odbywały się przez platformę umożliwiającą prowadzenie konferencji. Grupa utrzymała częstotliwość spotkań. Jednakże z uwagi na zakaz zgromadzeń, jej członkowie nie mogli organizować akcji protestacyjnych, które są kluczowym elementem działalności Akcji Ratunkowej dla Krakowa. Nadal jednak mogli służyć radą władzom miasta, poprzez zwracanie uwagi na istotne problemy ekologiczne za pomocą petycji czy listów otwartych.

W Wawelskiej Kooperatywie Spożywczej na początku marca został powołany sztab kryzysowy. Każdy z członków mógł wziąć w nim udział za pośrednictwem platformy Zoom. Omawiano tam listę zagadnień zawierającą dopuszczalną ilość zamówień, jakie Kooperatywa może realizować w warunkach pandemii, a także sposób płatności, sprzątania i dezynfekowania lokalu. Zostały sporządzone listy odbioru poszczególnych zamówień, a także listy produktów, które z powodu konieczności ich przepakowania musiały zostać usunięte z oferty sklepu. Zmieniono także sposób pakowania produktów, tak by zmniejszyć ryzyko zakażenia. Został skrócony dopuszczalny czas zamawiania produktów oraz wydłużony czas kompletowania zamówień, aby zapewnić bezpieczeństwo nabywcom i osobom pracującym przy ich przygotowaniu. Wprowadzono też odbiór na konkretną godzinę, co 
rozwiązało problem kolejek, w których mogło dojść do zakażenia. Na przełomie marca i kwietnia w Kooperatywie płatności dokonywano wyłącznie w formie bezgotówkowej. Zostało utworzone subkonto bankowe należące do Kooperatywy, jednak szybko wrócono do tradycyjnej płatności gotówką. Pojawiła się także nowa inicjatywa, czyli odbiór sąsiedzki. Kooperanci byli zachęcani do tego, aby jeśli robią zamówienie dla siebie, kontaktowali się z osobami mieszkającymi w okolicy w celu odbierania także ich zamówień i dostarczania ich sąsiadom, co pozwalało zmniejszyć ilość osób przychodzących do sklepu. Mimo tych zmian obroty w kooperatywie, z miesiąca na miesiąc wzrosły o prawie $50 \%$, dużo więcej osób zamawiało za dużo większe kwoty. $Z$ uwagi na fakt, że Kooperatywa jest niewielką grupą, zaszła konieczność wprowadzenia limitów zamówień.

Wybuch pandemii miał wielki wpływ także na Fundację Otwarty Plan. Główna działalność tej organizacji opiera się na bezpośrednim kontakcie z odbiorcami, więc czasowa izolacja zmusiła jej członków do okresowego zawieszenia działań. Respondent nadmienił, iż w ostatnim okresie działalność Fundacji skoncentrowana była na edukacji ekologicznej w szkołach na terenie Małopolski, gdzie realizowano całoroczne programy edukacyjne przeznaczone dla dzieci i młodzieży. Wybuch pandemii zmusił Fundację do przerwania realizacji programu, ponieważ placówki oświatowe zostały zamknięte. Pozostałe działania przeniesiono do przestrzeni internetowej. Grupa nie zawiesiła spotkań wewnętrznych, zespół pozostawał w kontakcie ze sobą przez cały okres przymusowej izolacji.

Podobnych odpowiedzi udzielił ostatni respondent z Krakowskiego Alarmu Smogowego. Epidemia w znaczący sposób wpłynęła na działalność tego ruchu społecznego, zmuszając jego zarząd i członków komisji rewizyjnej do przejścia na tryb pracy zdalnej. Także część planów uległa zmianie z racji przymusowej izolacji, między innymi nie ruszyła kampania związana z transportem publicznym. Jednakże ruch kontynuował swoje działania w trakcie pandemii, zorganizowano webinarium, czyli konferencję internetową w tej sprawie. Wzięło w nim udział wielu aktywistów i działaczy, osoby z Zarządu Transportu Publicznego w Krakowie oraz Paweł Silbert - burmistrz miasta Jaworzna. Zostały także opublikowane badania społeczne przeprowadzane wśród mieszkańców Krakowa. Aplikowano również do konkursów na projekty oraz prowadzono działalność doradczą, służąc radą władzom Krakowa w zakresie ekologii oraz inicjując uregulowania prawne mające na celu poprawę czystości powietrza w mieście.

$\mathrm{Na}$ drugie pytanie nie było jednoznacznych odpowiedzi. Według respondenta z Akcji Ratunkowej dla Krakowa sytuacja pandemii nie wpłynęła w znaczący sposób na postępowanie jej członków i sympatyków, zauważyła jednak, iż wiele z tych osób zaczęło doceniać zieleń miejską. Podczas niemal miesięcznej, przymusowej kwarantanny społeczeństwo, zdaniem respondenta, zaczęło zauważać jak istotny jest 
dla człowieka kontakt z naturą, a jego potrzeba może być zaspokojona np. poprzez spacer po parku. Jak wiadomo, znaczenie parków miejskich jest ogromne (Wronkowski, 2015). Aktywny bądź bierny wypoczynek w otoczeniu zieleni nie tylko przyczynia się do obniżenia poziomu stresu i zachowania zdrowia. Oprócz parków miejskich nazwą zieleń miejska można określić także inne tereny, takie jak skwery, promenady, ogrody botaniczne i działkowe, cmentarze czy kwietniki. Tereny te oprócz funkcji rekreacyjnej i estetycznej spełniają też rolę społeczno-wychowawczą, zwłaszcza ogrody przyszkolne, botaniczne i dendrologiczne. Tereny zielone także nawilżają powietrze i obniżają temperaturę panującą w miastach. Przyczyniają się również do redukcji poziomu hałasu.

Respondent z Wawelskiej Kooperatywy Spożywczej zauważył, iż zmiana wywołana przymusową izolacją znacząco wypłynęła na więzi w ich społeczności. Sytuacja pandemii zmusiła członków do ograniczenia kontaktów wewnątrz grupy oraz bezpośrednich kontaktów z rolnikami. Zawieszono całkowicie spotkania wprowadzające dla nowych osób, a spotkania wewnętrzne prowadzone były za pośrednictwem platformy internetowej Zoom. Zostało też odwołane istotne wydarzenie, czyli Urodziny Kooperatywy, zwyczajowo organizowane w czerwcu każdego roku. Respondent zwrócił uwagę na istotny fakt, iż wszyscy kooperanci w trosce o dobro pozostałych stosowali się do nakazu dezynfekcji rąk oraz noszenia maseczek na długo przed tym, zanim wprowadzono to odgórnie, czyli przez władze państwowe. Kierowała nimi solidarność z grupą, a nie obowiązek. Działo się tak dlatego, iż Wawelska Kooperatywa Spożywcza jest typowym przykładem grupy, w której typ więzi można określić terminem communitas.

Jak poinformował respondent z Fundacji Otwarty Plan, na początku, kiedy sytuacja pandemii nie była opanowana, liczba diagnozowanych zachorowań wzrastała, a publikowane komunikaty były coraz bardziej alarmujące, nastąpiło ograniczenie kontaktów osobistych w zespole Fundacji. Gdy tylko sytuacja uległa poprawie, wszyscy powrócili do pracy. Podobnie jak w przypadku pozostałych organizacji, izolacja niekorzystnie wpłynęła na kontakty w grupie, jednak nie zmieniła niczego w sposób znaczący.

Respondent z Krakowskiego Alarmu Smogowego odpowiedział, iż izolacja nie wpłynęła znacząco ani na członków ruchu, ani na sympatyków, poza koniecznością zmiany trybu pracy na zdalny. Zaobserwował jednak spadek zaufania do komunikacji publicznej. Na przełomie marca i kwietnia pojawiły się ograniczenia ilości podróżujących, niektóre z linii autobusowych lub tramwajowych zostały czasowo zawieszone lub też zmniejszyła się liczba kursów. W lipcu 2020 roku podano też informacje o planowanej podwyżce cen biletów, co zdaniem respondenta może prowadzić do zwiększenia ilości samochodów osobowych na drogach, a co za tym idzie zwiększonej emisji zanieczyszczeń. Respondent zauważa także, 
iż czasowa izolacja uwrażliwi ludzi na ekologię oraz sprawi, że bardziej docenią otaczającą ich naturę.

$\mathrm{Na}$ trzecie z pytań o to, co zmieni kryzys, odpowiedzi także były różnorodne. Respondent z Akcji Ratunkowej dla Krakowa zauważył, że jedynym ze skutków kryzysu mogą być próby oszczędzania środków finansowych, które mogą mieć negatywny wpływ na klimat, takie jak na przykład podwyżka cen biletów komunikacji publicznej. Zdaniem respondenta może to spowodować zwiększenie ilości samochodów na drogach, a przez to podwyższenie poziomu zanieczyszczenia powietrza w mieście.

Zdaniem respondenta z Wawelskiej Kooperatywy Spożywczej kryzys stwarza szerokie możliwości dla rozwoju Kooperatywy oraz inicjatyw jej podobnych. Ostatnie wydarzenia dowiodły, jak kruche są długie łańcuchy dostaw. Można o tym wywnioskować z niedawnych kłopotów z zaopatrzeniem, rosnących cen żywności czy ogromnych kolejek w sklepach. W kooperatywie nic takiego nie miało miejsca. Nie odnotowano braków żywności, oferta sklepu była niemal taka sama jak przed wybuchem epidemii. Co prawda kilka produktów usunięto, ale w ich miejsce pojawiły się nowe. Nie odnotowano także znaczącego wzrostu cen, poza niewielką podwyżką cen makaronów. Przyczyną zaistniałej zmiany nie była jednak pandemia, a susza przewidywana przez rolników. Nie było także kolejek, w odróżnieniu od reszty sklepów i marketów, choć wydłużył się nieco czas kompletowania zamówień.

Jak twierdzi respondent, w dobie kryzysu liczba podobnych inicjatyw jak Kooperatywa będzie wzrastać. Pojawia się również popyt na usługi dowozu warzyw i owoców bezpośrednio z gospodarstw rolnych. Odbywa się to na tej zasadzie, że gospodarstwo przygotowuje paczkę z produktami i dowozi je do klienta. Jak zauważył mój rozmówca, jedno z zaprzyjaźnionych z Kooperatywą gospodarstw wdrożyło taką inicjatywę i miało kłopot z terminową realizacją zamówień, z uwagi na ich dużą liczbę. Konsumenci pozbawieni możliwości zakupienia posiłku na mieście stanęli przed koniecznością samodzielnego jego przygotowania, w wielu przypadkach przekonali się, jak wielkie znaczenie ma jakość pożywienia. Ponadto ludzie nie zgadzają się, aby żywność ekologiczna była dobrem ekskluzywnym, z tej przyczyny kiełkują inicjatywy podobne do Kooperatywy, w których członkowie mają dostęp do zdrowej żywności sprzedawanej po przystępnych cenach, jak na przykład Krakowska Farma Miejska, w której mieszkańcy Krakowa zajmują się uprawą i dostarczaniem ekologicznych warzyw, zgodnie z naturalnym rytmem natury. W dobie pandemii zwiększyło się zainteresowanie także tą grupą i w krótkim czasie uzyskała ogromną popularność. Obecnie, co tydzień zaopatruje od dwudziestu do trzydziestu mieszkańców Krakowa (Gawlik, 2020). Kryzys może też wywołać falę migracji z miasta na wieś. Zdaniem respondenta taki stan rzeczy uwarunkowany jest rosnącą potrzebą bycia samowystarczalnym żywieniowo. Długie tygodnie izolacji, zdaniem 
mojego rozmówcy pokazały także wielu ludziom, jak bardzo człowiek jest zależny od natury. Negatywnym skutkiem pandemii, zdaniem respondenta, będzie znaczne osłabienie więzi międzyludzkich. Jednakże respondent jest dobrej myśli, twierdzi, iż Wawelska Kooperatywa Spożywcza ma wielką szansę się rozwinąć. Dzieje się tak, ponieważ Kooperatywę tworzy grupa ludzi, których relacje są bezpośrednie, oparte na solidarności i dbałości o wspólny interes.

Respondent z Fundacji Otwarty Plan na trzecie pytanie o skutki i dalsze perspektywy działalności odpowiedział, iż „duża część działań edukacyjnych prowadzonych przez Fundację związana jest z pracą z placówkami oświatowymi. Ich wyłączenie z normalnego funkcjonowania, nieuczęszczanie uczniów i uczennic do szkoły, ma bezpośredni wpływ na realizację programów edukacyjnych”. Fundacja obecnie poszukuje nowych możliwości współpracy, w sytuacji, kiedy kadra szkół zachowuje dystans w kontakcie z podmiotami zewnętrznymi.

Respondent z Krakowskiego Alarmu Smogowego na trzecie pytanie udzielił następującej odpowiedzi: „Nic nie się nie zmieni, zmienił się tylko modus operan$d i$, nie zmieniły się także plany samego ruchu. Jednakże rozmówca przewiduje, iż na gorsze sytuacja może zmienić się znacząco, z uwagi na idący kryzys. Miasto może szukać oszczędności nie zawsze w przemyślany i konieczny sposób, jak na przykład podniesienie cen biletów za transport publiczny. Jeśli chodzi o mieszkańców Krakowa, w dobie kryzysu można założyć, że ludność z uwagi na niższe dochody może wykazywać mniejszą aprobatę dla odnawialnych źródeł energii oraz ograniczoną skłonność do wymiany ogrzewania na bardziej ekologiczne.

\section{Podsumowanie}

Na podstawie rezultatów tej mini ankiety można wnioskować, iż organizacje takie jak Wawelska Kooperatywa Spożywcza, czy ruchy społeczne takie jak Krakowski Alarm Smogowy wykazują sporą odporność na kryzys. Wszyscy badani wypowiedzieli się jednoznacznie: zmianie uległ jedynie tryb pracy, a działalność nie została ani na chwilę zawieszona. Jednym z powodów może być fakt, iż małe organizacje, w których pracuje niewielka ilość osób, są stabilniejsze, łatwiej w nich rozłożyć zadania czy skomunikować się w sprawach wymagających natychmiastowych działań. Ponadto we wszystkich badanych grupach typ więzi pomiędzy ludźmi można określić terminem communitas. Może to stanowić wielki atut w trakcie kryzysu, gdyż pozwala przypuszczać, iż członkowie będą pracować nie tylko dla swojego, ale także dla dobra innych członków oraz dążyć do utrzymania spójności grupy. Taki typ działania odróżnia badane organizacje od tych, które skupiają wiele osób, na przykład od korporacji, w których zatrudnieni nie mają okazji, by dobrze poznać 
swoich współpracowników, dlatego też więzi w nich są niezwykle kruche i ograniczone do kontaktów czysto formalnych. W organizacjach o charakterze globalnym nie obserwuje się kontaktów opartych o typ communitas, dlatego wykazują większą podatność na zmianę i rozpad więzi.

O zaletach takiego modelu funkcjonowania grupy można wnioskować na przykładzie Wawelskiej Kooperatywy Spożywczej, w której obroty znacząco wzrosły. Nie obserwowano w niej kolejek, sklep funkcjonował sprawnie, a ceny żywności utrzymują się na jednakowym poziomie w stosunku do cen sprzed pandemii. Można zatem sądzić, iż mniejsze grupy, w których przeważają kontakty bezpośrednie, wykazują się stabilnością i sporą odpornością na kryzys. Ponadto we wszystkich grupach, czy to w Fundacji, czy Krakowskim Alarmie Smogowym, ludzie zrzeszeni są w określonym celu związanym z ekologią i działaniem dla wspólnego dobra. Mogą także posłużyć doświadczeniem samorządom miejskim. Choć trudno przewidzieć, jaki kierunek działań obiorą te organy, ale to jak miasta przetrzymają kryzys, w dużej mierze zależy od ich polityki. Jak pisze Paweł Kubicki, jeśli górę wezmą polityczne lub biznesowe interesy, a nie dobro całego miasta jako wspólnoty, to bez wątpienia właśnie na samorządzie miejskim skupi się frustracja mieszkańców, którzy odczują skutki kryzysu po pandemii. Inaczej będzie wyglądać sytuacja, jeśli mieszkańcy miast, wzorem sympatyków i uczestników ekologicznych ruchów społecznych, fundacji i innych grup będą mieli świadomość, że przez ten kryzys przechodzą wspólnie i na takich samych zasadach jak władze samorządowe.

\section{Bibliografia}

Appadurai A. (2005). Nowoczesność bez granic. Przekład Zbigniew Pucek. Kraków: Wydawnictwo Universitas.

Bauman Z. (1999). Po co komu teoria zmiany. W: Zmiana spoteczna. Teorie i doswiadczenia polskie. J. Kurczewska (red.). Warszawa: Wydawnictwo IFiS PAN encenc.pl/amerykanizacja.

Gawlik K. (2020). Dostęp on-line: smoglab.pl/krakowska-farma-miejskadostarcza-warzywa-nie-wedlug-zyczen-ale-rytmu-natury/?fbclid=IwAR1NW0 HIXGL2cBaZKd6zlOZGIFj_RiJOFxRn-qqPYPtf72Klg1c.

Juszczyk S. (2013). Badania jakościowe w naukach spotecznych szkice metodologiczne.

Dostępny online: wydawnictwo.us.edu.pl/sites/wydawnictwo.us.edu.pl/files/ badania_jakosciowe_-_czw_st.pdf.

Konecki K. (2000). Studia z metodologii badań jakościowych. Teoria ugruntowana. Warszawa: Wydawnictwo PAN. 
Kostera M. (2011). Obserwacja uczestniczaca. Dostęp on-line www.kostera.pl/documents/2_MetodyMSM.pdf.

Kubicki P. (2020). Odporność miast musi być oparta na wspólnocie. Dostęp on-line: www.kongresobywatelski.pl/idee-dla-polski-kategoria/odpornosc-miast-musi-byc-oparta-na-wspolnocie.

Niedźwiedzki D. (2003). Wtadza. Tożsamość. Zmiana społeczna. Kraków: Wydawnictwo Universitas.

Nieporowski P. (2015). Etyka niejawnej obserwacji uczestniczacej jako metody badawczej stosowanej w naukach spotecznych. Dostęp on-line: cejsh.icm.edu.pl/ cejsh/element/bwmeta1.element.desklight-a139063f a8ad-4b36-a989-6c00a6b6a1a9?q=232d408e-6014-43f0-bca8 1b689ed6d0b6\$2\&qt=IN_PAGE. ozkultura.pl/wpis/7578/16.

Ritzer G. (1997). Mcdonaldyzacja spoteczeństwa. Przekład Sławomir Magala. Warszawa: Wydawnictwo Literackie Muza.

Turner V. (2010). Proces rytualny struktura i antystruktura. Przekład Ewa Dżurak. Warszawa: Państwowy Instytut Wydawniczy.

Wronkowski A. (2015). Positive Effects of the COVID-19 Pandemic in the Ecological Area of Social Movements. Dostęp on-line: urbnews.pl/istota-zieleni-w-przestrzeni-miejskiej.

\title{
Positive effects of COVID-19 pandemic in the area of ecological social movements
}

\begin{abstract}
This article decscribes the situation of social movements, foundations and groups that have set themselves the goal of taking care of the environment in the city as well as providing their members with organic food, from local farmers, in the time of a pandemic. It describes the results of research carried out at the turn of August and September 2020 in Cracow. The respondents were members of groups such as the Krakowski Alarm Smogowy, Fundacja Otwarty Plan, Wawelska Kooperatywa Spożywcza and Akcja Ratunkowa dla Krakowa. It addresses the impact of isolation on the functioning of the above-mentioned social movements, foundations and groups. Moreover, it deals with the subject of communitas ties and the durability of groups based on this type of social ties. A significant part of the article is also devoted to forecasts and assumptions as to how life in cities may change and what impact the crisis in the service industry has on the city itself.
\end{abstract}

Keywords: ecology, pandemic, social movements. 